\title{
Biophysical Modeling of Dietary Energy in Biochemical Modeling
}

\author{
Md. Abdul Hakim \\ Department of Food Technology and Nutritional Science, Mawlana Bhashani Science and Technology University, Santosh, Tangail, \\ Bangladesh
}

\section{Email address: \\ info.hakim.bd@gmail.com}

\section{To cite this article:}

Md. Abdul Hakim. Biophysical Modeling of Dietary Energy in Biochemical Modeling. European Journal of Biophysics.

Vol. 5, No. 3, 2017, pp. 57-61. doi: 10.11648/j.ejb.20170503.12

Received: February 27, 2017; Accepted: March 7, 2017; Published: October 21, 2017

\begin{abstract}
The measurement of total dietary energy is in great triumph on the helm of designing an apt dieting in normal and therapeutic diet. The prevailing procedures in this arena are relatively time consuming, laboratory tests induced and often the misleading data contributors while planning a balanced dieting in nutrition counseling. The dietician is sometimes at bay in the route ahead of perfect dieting to hold up nutritional soundness of the sample at a population in a community. The aim of this current study is making a dot over these ongoing perils exploring a mathematical modeling used in prescribing a confounding free diet. The study can divulge an open secret in measuring total dietary energy to curb the possible health horrors in worldwide nutritional epidemiology. The study finding is the determinant of total dietary energy (DTDE) [equation (16)] can be a splendid biophysical modeling as a dieting tool in human nutrition.
\end{abstract}

Keywords: Biophysical Modeling, Dietary Energy, Co-efficient of Total Dietary Energy (CTDE), Nutritional Physics, Biochemical Modeling, Health Pedagogy

\section{Introduction}

About 2 billion people in the world suffering from different forms of malnutrition [1]. Malnutrition is an underlying cause of death of about 2.6 million children each year $[2,3]$.

Malnutrition is the premier causes of stunted growth and increasing mortality and morbidity rates [4-7]. About 4 of each 5 malnourished children in South-East-Asian (SEA) regions contributing about $83 \%$ of their deaths due to mild to moderate malnutrition [8-10]. Malnutrition in developing countries is on action due to poverty, household food insecurity, gender bias, population pressure, food taboos, health, hygiene and nutritional negligence, famine and manmade disasters [11-15]. Malnutrition also occurring for intrafamily feud, lower class livelihood, child abuse, deprivation of schooling opportunity and consequence of faulty family planning practices in their families [16-19]. These nutritional giants are engulfing the population and therefore initiatives are in need of galore need to shirk these malnutrition facing factors [20, 21].

Therefore, this study was conducted to form an effective dieting tool to help the dietician to plan the proper dieting for both the therapeutic and normal diet aiming to turn tail the ongoing malnutrition headache across the globe and the government and different international and national NGOs are urged to organize health and nutritional campaigning to aid the population to practice a healthy diet using this study proposed determinant of total dietary energy (DTDE) in nutritional physics.

\section{Data Sources and Methodology}

The study was a cross-sectional study using secondary data analysis method. The data were collected from the biophysical equation of dietary energy, fuel factor and the mass of consuming nutrients in the branch of human physiology. The logarithmic modeling of equations from mathematics was in application to undergo in analyzing all the data using mathematical modeling to hit upon a trendy and time saving biophysical modeling to calculate total dietary energy needed for individuals in the communities due to consumption of foods. 


\section{Results}

Dietary energy is the amount of energy released in human body through the digestion and absorption of foods associated in a diet [22-25]. Biophysically, it is the product of fuel factor and mass of consuming foods [26-29].

So,

$$
\mathrm{E}_{\mathrm{d}}=\mathrm{fm} \text {; }
$$

Where,

$\mathrm{F}=$ fuel factor of food,

$\mathrm{M}=$ mass of food in $\mathrm{g}$ and

$$
\mathrm{E}_{\mathrm{d}}=\text { Dietary energy in kcal }
$$

The human diet comprises three main sources of dietary energy naming carbohydrates, proteins and fats among the six components in the diet and lesser degree of alcohol [30-32].

Let,

The fuel factors of carbohydrates, proteins, fats and alcohol be $f_{c}, f_{p}, f_{f}$ and $f_{a} k_{c a l ~}{ }^{-1}$ to be responsible to yield $\left(E_{d}\right)_{c}, \quad\left(E_{d}\right)_{p}, \quad\left(E_{d}\right)_{f}$ and $\left(E_{d}\right)_{a}$ kcal of dietary energy for corresponding consumption of $\mathrm{m}_{\mathrm{c}}, \mathrm{m}_{\mathrm{p}}, \mathrm{m}_{\mathrm{f}}$ and $\mathrm{m}_{\mathrm{a}} \mathrm{g}$ of carbohydrates, proteins, fats and alcohol respectively.

So, considering the equation (1) in the gesture of carbohydrates, proteins, fats and alcohol consumption,

$$
\begin{aligned}
& \left(E_{d}\right)_{c}=f_{c} m_{c} \\
& \left(E_{d}\right)_{p}=f_{p} m_{p} \\
& \left(E_{d}\right)_{f}=f_{f} m_{f} \\
& \left(E_{d}\right)_{a}=f_{a} m_{a}
\end{aligned}
$$

Adding the equations (2), (3), (4) and (5),

$$
\left(E_{d}\right)_{c}+\left(E_{d}\right)_{p}+\left(E_{d}\right)_{f}+\left(E_{d}\right)_{a}=f_{c} m_{c}+f_{p} m_{p}+f_{f} m_{f}+f_{a} m_{a}(6)
$$

None but carbohydrates, proteins, fats and alcohol are the dietary energy yielders in bromatology [33].

Hence,

$$
\left(E_{d}\right)_{c}+\left(E_{d}\right)_{p}+\left(E_{d}\right)_{f}+\left(E_{d}\right)_{a}=\left(E_{d}\right)_{T} ;
$$

Where,

$$
\left(E_{d}\right)_{T}=\text { Total dietary energy. }
$$

Putting the value of equation (7) in equation (6),

$$
\left(E_{d}\right)_{T}=f_{c} m_{c}+f_{p} m_{p}+f_{f} m_{f}+f_{a} m_{a}
$$

The fuel factors of carbohydrates, proteins, fats and alcohol representing $f_{c}, f_{p}, f_{f}$ and $f_{a}$ are $4,4,9$ and $7 \mathrm{kcal} \mathrm{g}^{-1}$ [34-37].

So,

$$
\begin{aligned}
& f_{c}=4 \\
& f_{p}=4 \\
& f_{f}=9
\end{aligned}
$$

$$
\mathrm{f}_{\mathrm{a}}=7
$$

Inserting the value of equations (9), (10), (11) and (12) into equation (8),

$$
\begin{aligned}
\left(\mathrm{E}_{\mathrm{d}}\right)_{\mathrm{T}} & =4 \mathrm{~m}_{\mathrm{c}}+4 \mathrm{~m}_{\mathrm{p}}+9 \mathrm{~m}_{\mathrm{f}}+7 \mathrm{~m}_{\mathrm{a}} \\
& =4 \mathrm{~m}_{\mathrm{c}}+4 \mathrm{~m}_{\mathrm{p}}+4 \mathrm{~m}_{\mathrm{f}}+5 \mathrm{~m}_{\mathrm{f}}+4 \mathrm{~m}_{\mathrm{a}}+3 \mathrm{~m}_{\mathrm{a}} \\
& =4 \mathrm{~m}_{\mathrm{c}+}+4 \mathrm{~m}_{\mathrm{p}}+4 \mathrm{~m}_{\mathrm{f}}+4 \mathrm{~m}_{\mathrm{a}}+5 \mathrm{~m}_{\mathrm{f}}+3 \mathrm{~m}_{\mathrm{a}} \\
& =4\left(\mathrm{~m}_{\mathrm{c}}+\mathrm{m}_{\mathrm{p}}+\mathrm{m}_{\mathrm{f}}+\mathrm{m}_{\mathrm{a}}\right)+5 \mathrm{~m}_{\mathrm{f}}+3 \mathrm{~m}_{\mathrm{a}} \\
& =4 \sum \mathrm{m}_{\mathrm{c}, \mathrm{p}, \mathrm{f}, \mathrm{a}}+5 \mathrm{~m}_{\mathrm{f}}+3 \mathrm{~m}_{\mathrm{a}}
\end{aligned}
$$

Taking $\log$ [38-40] on the equation (13),

$$
\left(E_{d}\right)_{T}=\log { }^{-1} \log \left(4 \sum m_{c, p, f, a}+5 m_{f}+3 m_{a}\right)
$$

Let,

$$
\log \left(4 \sum \mathrm{m}_{\mathrm{c}, \mathrm{p}, \mathrm{f}, \mathrm{a}}+5 \mathrm{~m}_{\mathrm{f}}+3 \mathrm{~m}_{\mathrm{a}}\right)=\mathrm{e}_{\mathrm{d}}
$$

Where,

$\mathrm{e}_{\mathrm{d}}=$ Co-efficient of total dietary energy (CTDE).

Inflowing the equation (15) into equation (14),

$$
\left(\mathrm{E}_{\mathrm{d}}\right)_{\mathrm{T}}=\log ^{-1} \mathrm{e}_{\mathrm{d}}
$$

The equation (16) can be used to determine the total dietary energy in human physiology as so this linear equation could be marked as the determinant of total dietary energy (DTDE) in health science and nutritional physics [41-48].

\section{Discussion}

Human health is the level of function or metabolic ability of individuals or communities to adapt and self-manage during physical, mental and social challenges [49-51]. The WHO defines health in a broader sense on its 1948 constitution as "a state of complete physical, mental, and social well-being and not merely the absence of disease or infirmity" [52]. To maintain healthy health is really harder due to different physical, social, economic and environmental affecting factors. The people are often deprived of their country's constitution named basic health, hygiene, nutritional care and shelter [53-55]. The population is want of balanced diet for frequent occurring dieting malpractices and the dieticians are in quest of a time saving and easy method in measuring total dietary energy needed for the observance of healthy population [52] in the community. There are different degree of health and nutritional problems such as concept of mass, dietary energy, fuel factor and the information gap between the dietary energy and total dietary energy in nutritional physics. The study proposed determinant of total dietary energy (DTDE) in human physiology can be a solvable bid in overcoming different problems during designing an apt dieting in nutrition counseling [56-59]. The present study result is cut and dried by adding the fuel factor of alcohol along with other energy 
yielders naming carbohydrates, proteins and fats. The $\left(E_{d}\right)_{T}$ evaluating method is cut short using the result of the study [equation (16)] in name of the determinant of total dietary energy (DTDE) in human physiology. This study proposed determinant of total dietary energy (DTDE) can be an effective spatial microsimulation modeling [60-63] to be constructive in designing policies for the governments and NGOs for environmental and spatial effects across different countries [64-66] in the world to aid healthy dieting practices [67-69] for sustaining sound health. This health microsimulation modeling [equation (16)] gained from the carried out study can be an effective tool at health pedagogy [70-74] in nutritional epidemiology. This health microsimulation modeling i. e. the logarithmic equation (16) can be an effective policy in maintaining health and nutritional soundness of population in nutritional statistics. This study proposed determinant of total dietary energy (DTDE) can be in vast application while sustaining sound health of population gaining health status in nutritional epidemiology determined using the logarithmic biophysical modulator of health status in statistical modeling [75].

\section{Conclusion}

Malnutrition is the crying happening in the developed and developing countries. The present study results can take a serious turn in evading the malnutrition across the globe. This study rendering determinant of total dietary energy (DTDE) should be taking into action in designing healthy diet at different demographic sites in the world. So the national and international think tank should bear the testimony in making awareness on the determinant of total dietary energy (DTDE as a part of effective dieting tools in nutrition counseling. Future research should adopt this hassle free $\left(E_{d}\right)_{T}$ measuring modeling to explore a new road in health pedagogy for taking intervention in policy designing, analysis and checking spatial effects for health and nutrition condition upgrading bid for all classes' people.

\section{References}

[1] IFAD/FAO/WFP. The state of food insecurity in the world 2011, In Rome, Italy: FAO.

[2] UN inter-agency group for child mortality estimation. Levels and trends in child mortality: Report 2011, New York: UNICEF.

[3] Megabiaw B and Rahman A. Prevalence and determinants of chronic malnutrition among under-5 children in Ethiopia. Int $J$ Child Health Nut 2013; 2 (3): 230-236.

[4] Hakim MA and Kamruzzaman M. Nutritional status of preschoolers in four selected fisher communities. Am J Life Sci 2015; 3 (4):332-336.

[5] Rahman A and Hakim MA. Malnutrition prevalence and health practices of homeless children: a cross-sectional study in Bangladesh. Sci J Public Health 2016; 4 (1-1): 10-15.
[6] Rahman A and Chowdhury S. Determinants of chronic malnutrition among preschool children in Bangladesh. $J$ Biosoc Sci 2007; 39 (2): 161-173.

[7] Genton B, Al-Yaman F, Ginny M, Taraika J and Alpers MP. Relation of anthropometry to malaria morbidity and immunity in Papua New Guinean. Am J Clin Nutr 1998; 68: 734-41.

[8] Rahman A and Hakim MA. An epidemiological study on hygiene practice and malnutrition prevalence of beggars children in Bangladesh. Int J Nutr Diet 2016; 4 (1): 29-46.

[9] UNICEF. Malnutrition in South Asia; A Regional Profile, UNICEF report, 1997; p. 8.

[10] Rahman A, Chowdhury S and Hossain D. Acute malnutrition in Bangladeshi children: levels and determinants. Asia Pac J Public Health 2009; 21 (1): 294-302.

[11] Hakim MA, Talukder MJ and Islam MS. Nutritional status and hygiene behavior of government primary school kids in central Bangladesh. Sci J Public Health 2015; 3 (5): 638-642.

[12] Fakir AMS and Rahman MW. Determinants of malnutrition among urban slum children in Bangladesh. Health Educ Rev $2015 ; 5: 22$.

[13] Kamruzzaman M and Hakim MA. Child criminalization at slum areas in Dhaka city. Am J Psycho Cog Sci 2015; 1 (4): 107-111.

[14] Ghosh S and Shah D. Nutritional problems in urban slum children. Ind Pediatr 2004; 41 (7): 682-696.

[15] Hakim MA and Kamruzzaman M. The dance of poverty and education for childhood nutritional victimization in Bangladesh. J Biolog Env Engg 2016; 1 (1): 6-9.

[16] Weitzmawqn M. Excessive school absence. Adv Develop Behav Pediatr 1987; 8: 151-78.

[17] Kamruzzaman M and Hakim MA. Family planning practices among married women attending primary health care centers in Bangladesh. Int J Bioinfo Biomed Engg 2015; 1 (3): 251255.

[18] Kamruzzaman M and Hakim MA. Socio-economic status of child beggars in Dhaka city. J Soc Sci Human 2015; 1 (5): 516-520.

[19] Kamruzzaman M and Hakim MA. Basic rights on the wane, human rights on brown study: a case study on thrown away children in Bangladesh. J Env Plan Manage 2016; 2 (4): 2935 .

[20] Rahman A. Significant risk factors for childhood malnutrition: evidence from an Asian developing country. Sci J Public Health 2016; 4 (1-1): 16-27.

[21] Hoddinott J, Rosegrant $\mathrm{M}$ and Torero M. Challenge paper: hunger and malnutrition 2012.

[22] Sampey BP, Vanhoose AM, Winfild HM, Freemerman AJ, Muehlbauer MJ, Fueger PT, Newgard CB and Makowski L. Cafeteria diet is a robust model of human metabolic syndrome with liver and adipose inflammation: comparison to high-fat diet. Obesity 2011; 19 (6): 1109-1117.

[23] Ledikwe JH, Blank HM, Kettel KL, Serdula MK, Seymour JD, Tohill BC and Rolls BJ. Dietary energy density is associated with energy intake and weight status in US asdults. Am J Clin Nutr 2006; 83 (6): 1362-8. 
[24] Linkon MR, Prodhan UK, Elahi T, Talukder J, Alim MA and Hakim MA. Comperative analysis of the physicochemical and antioxidant properties of honey available in Tangail, Bangladesh. Int J Res Engg Tech 2015; 4 (3): 89-92.

[25] Makowski L and Hotamisligil GS. Fatty acid binding proteinsthe evolutionary crossroads of inflammatory and metabolic response. J Nutr 2004; 134: 2464S-2468S.

[26] Linkon KMMR, Prodhan UK, Hakim MA and Alim MA. Study on the physicochemical and antioxidant properties of nigella honey. Int J Nutr Food Sci 2015; 4 (2):137-140.

[27] Kane G. The mysteries of mass. Scientific American (Nature America, Inc.) 2008; p. 32-39.

[28] Hakim MA. Physicochemical properties of dhania honey. Am J Food Sci Nutr Res 2015; 2 (5): 145-148.

[29] Jammer M. Concept of mass in classical and modern physics, New York: Dover, 1997.

[30] Buffy G. Kupffer cells in non-alcoholic fatty liver disease: the emerging view. J Hepatol 2009; 51: 212-223.

[31] Rolls BJ. The relationship between dietary energy density and energy intake. Physiol Behav 2009; 97: 609-615.

[32] Despres JP. Is visceral obesity the cause of metabolic syndrome. Ann Med 2006; 38: 52-63.

[33] Huq AKO. Human Nutrition and Applied Dietetics ( $1^{\text {st }}$ edn) 2012; p. 31.

[34] Hakim MA and Islam MS. Elementary of Food Science and Technology ( $1^{\text {st }}$ edn) 2016 ; p. 36.

[35] Mitchell MC and Herlong HF. Alcohol and nutrition: calorie value, bioenergies and relationship to liver damage. Annu Rev Nutr 1986; 6: 457-74.

[36] Joshi SA. Nutrition and Dietetics ( $2^{\text {nd }}$ edn) 2002, p. 31.

[37] Wilson GB, Kaner EFS, Croslard A, Ling J and Haighton CA. Quantitative study of alcohol, health and identities among UK adults in later life. PLoS ONE 2013; 8 (8): e71792.

[38] Shirali S. A premier in logarithm, Hyderabad: Universities Press 2002.

[39] Gulberg J. Mathematics: from the birth of numbers, New York: W. W. Norton \& Co. 1997.

[40] Kate SK and Bhapkar HR. Basics of mathematics, Pune: Technical publications 2009.

[41] Bernard JE and Bright GW. Students performance in solving linear equations. Int J Math Educ Sci Tech 2006; 15: 399-421.

[42] Denzer CM and Young CG. The effect of résistance exercise on the thermal effect of food. Int J Sports Nutr Exercise Metab 2003; 13(3): 396-402.

[43] Rahman A and Hakim MA. Measuring modified mass energy equivalence in nutritional epidemiology: a proposal to adapt the biophysical modelling approach. Int J Stat Med Res 2016; 5 (3) $219-223$.

[44] Einstein A. Ist dies tragheit eines korpers von seinem energieinhalt abhangig? Annalen der Physik 1905; 18: 639643.

[45] Kittel C and Kroemer H. Thermal physics. Macmillan 1980.
[46] Hakim MA and Rahman A. Health and nutritional condition of street children of Dhaka city: an empirical study in Bangladesh. Sci J Public Health 2016; 4 (1-1) 6-9.

[47] Sadava D and Orians G. Life: The science of biology. New York: W. H. Freeman and Co. 2000; p. 887.

[48] Rahman A, Hakim MA, Hanif MA, Islam MR and Kamruzzaman M. Dietary practices, health status and hygiene obserbance of slum kids: a pilot study in an Asian developing country. JP J Biostat 2016; 13 (2): 195-208.

[49] Huber M, Knottnerus JA, Green L, van der Horst AR, Kromhout D and Smid H. BMJ 2011; 343 (d4163).

[50] Kamruzzaman M and Hakim MA. Socioeconomic status of slum dwellers on the capital city of Bangladesh. Am J Bisiness Society 2016; 1 (2): 13-18.

[51] Kamruzzaman M, Hakim MA, Hanif MA, Rahman MH, Islam MA, Talukder MR and Islam MR. Patterns of behavioral changes among adolescent smokers: an empirical study. Front Biomed Sci 2016; 1 (1): 1-6.

[52] WHO. Constitution of the World Health 2006.

[53] Hakim MA. Nutrition on malnutrition helm, nutrition policy in fool's paradise. The Daily Observer, 2015. Available on http://www.observerbd.com/2015/09/20/111732.php. (Accessed on September 20, 2015).

[54] Hakim MA. Nutritional status and hygiene practices of primary school goers in gateway to the north Bengal. Int $J$ Public Health Res 2016; 3 (5): 271-275.

[55] Islam MS, Hakim MA, Kamruzzaman M, Safeuzzaman, Haque MS and Alam MK. Socioeconomic profile and health status of rickshaw pullers in rural Bangladesh. Am J Food Sci Health 2016; 2 (4): 32-38.

[56] Hakim MA. Malnutrition prevalence and nutrition counseling in developing countries: a case study. Int J Nurs Health Sci 2016; 3 (3): 19-22.

[57] Hakim MA. Nutrition counseling in homelessness: a NC4HD nexus. Int J Health Econ Pol 2017; 2 (1): 12-15.

[58] Hakim MA and Talukder MJ. An assessment of health status of street children in Tangail, Bangladesh. Sci J Public Health 2016; 4 (1-1): 1-5.

[59] Hakim A. Vitamin A deficiency as a global public health threat: a concern in nutritional victimization. $J$ Nutr Health Food Engg 2016; 4 (5): 00147.

[60] Rahman A, Harding A, Tanton R and Liu S. Methodological issues in spatial microsimulation modelling for small area estimations. Int J Microsimul 2010; 3 (2): 3-22.

[61] Rahman A and Harding A. Spatial analysis of housing stress estimation in Australia with statistical validation. Aust $J$ Reg Stud 2014; 20 (3): 452-486.

[62] Rahman A, Harding A, Tanton R and Liu S. Simulating the characteristics of populations at the small area level: New validation techniques for a spatial microsimulation model in Australia. Comput Stat Data Analysis 2013; 57 (1): 149-165.

[63] Islam D, Ashraf M, Rahman A and Hasan R. Quantitative Analysis of Amartya Sen's Theory: An ICT4D Perspective. Int J Info Commu Tech Human Dev 2015; 7 (3): 13-26. 
[64] Phill M. Small area housing stress estimation in Australia: Microsimulation modeling and statistical reliability, University of Canberra, Australia 2011.

[65] Rahman A. Small area estimation through spatial microsimulation models: Some methodological issues, Paper presented at the $2^{\text {nd }}$ General Conference of the International Microsimulation Association, The National Conference Centre Ottawa, Canada 2009; p. 1- 45 (June 8 to 10).

[66] Rahman A and Upadhyay S. A Bayesian reweighting technique for small area estimation. Current Trends in Bayesian Methodology with Applications, CRC Press, London 2015; p. 503-519.

[67] Connolly J, Romano T and Patruno M. Effects of dieting and exercise on resting metabolic rate and implications for weight management. Fam Pract 1999; 16 (2): 196-201.

[68] Malinauskas BM, Raedeke TD, Aeby VG, Smith JL and Dallas MB. Dieting practices, weight perceptions and body composition: a comparison of normal weight, overweight and obese college females. Nutr J 2006; 5: 11.

[69] Kim JS. Experiences in healthy dieting of male college students with obesity in Korea. Osong Public Health Res Perspect 2015; 6 (1): 59-63.
[70] Poole SA, Hart CN, Jelalian E and Raynor HA. Relationship between dietary energy and dietary quality in overweight young children: a cross-sectional analysis. Pediatr Obesity 2016; 11 (2): 128-135.

[71] Karsten K. Educational Theory as Tropical Rheotic: The Concepts of Pedagogy of Johann Freidrich Herbert and Freidrich Schleiermacher. Stud Philosophy Educ 2012; 31 (1): 265-273.

[72] Rahman A and Harding A. Prevalence of overweight and obesity epidemic in Australia: some causes and consequences. JP J Biostat 2013; 10 (1): 31-48.

[73] Hakim MA and Kamruzzaman M. Nutritional status of central Bangladesh street children. Am J Food Sci Nutr Res 2015; 2 (5): 133-137.

[74] Kuddus A, Rahman A, Talukder MR and Hoque A. A modified SIR model to study on physical behaviour among smallpox infective population in Bangladesh. Am J Math Stat 2014; 4 (5): 231-239.

[75] Rahman A and Hakim MA. Modeling health status using the logarithmic biophysical modulator. $J$ Public Health Epodemiol, in press. 